Bangladesh J. PI. Breed. Genet, 24(1): 45-51

\title{
GENETIC VARIABILITY AND CHARACTER ASSOCIATION FOR AGRONOMIC TRAITS IN HYBRID RICE (Oryza Sativa L.)
}

\author{
M. J. Hasan, M. U. Kulsum, A. Akter, A. S. M. Masuduzzaman and M. S. Ramesha ${ }^{1}$ \\ Hybrid Rice Section \\ Bangladesh Rice Research Institute \\ Gazipur 1706, Bangladesh.
}

\begin{abstract}
Twenty four hybrid rice varieties of diverse origin were studied for genetic variability, correlation and path analysis under medium high land of Gazipur. The PCV values were greater than GCV, revealing little influence of environment in character expression. High values of heritability along with moderate genetic advance were observed for panicle $/ \mathrm{m}^{2}$, days to $50 \%$ flowering and plant height. Grain yield showed positive significant association with number of effective tillers/hill, panicle $/ \mathrm{m}^{2}$, spikelet fertility and thousand grain weight at both genotypic and phenotypic levels. Same traits had highest significant positive effect on yield.
\end{abstract}

Key words: Genetic variability, correlation, path analysis, hybrid rice

\section{INTRODUCTION}

Bangladesh has made notable technological progress in rice cultivation over the last two decades, which has contributed to achieving food security despite doubling of population and a reduction in arable land since its independence in 1971. Cereal production increased from 10.0 million MT (1971) to 35.0 million MT in 2010 reducing hunger and poverty but still we are facing food shortage. The population will increase to over 4.6 billion by 2050 (Honarnejad et al., 2000) which demands more than $50 \%$ of rice needs to be produced (Ashikari et al., 2005, Srividya et al., 2010).

The hybrid rice is being the new answer to the growing hunger of world population; by the way of its elevated yield potential, agronomic performance and disease resistance. Genetic variability, correlation and path coefficients are pre-requisites for improvement of any crop including rice in any trait by selection of superior genotypes. Yield component directly or indirectly increasing grain yield if the components are highly heritable and genetically independent or positively correlated with grain yield. It is very difficult to judge whether observed variability is highly heritable or not. Moreover, knowledge of heritability is essential for selection based improvement as it indicates the extent of transmissibility of a character into future generations. Knowledge of correlation between yield and its contributing characters are basic and fore most endeavor to find out guidelines for plant selection. Partitioning of total correlation into direct and indirect effect by path analysis helps in making the selection more effective. Keeping in view the above facts, the present investigation was undertaken to know variability and correlation among yield and its contributing characters using 24 rice hybrids under direct seeded condition in a medium high land.

\footnotetext{
${ }^{1}$ Rice Breeder, CSISA project, Barwale Foundation, Hyderabad, India
} 


\section{MATERIALS AND METHODS}

The experiment was conducted at Bangladesh Rice Research Institute, Gazipur, during Aus season, 2010. The trial was conducted with twenty four hybrid rice varieties collected from different parts of Bangladesh. The trial was set in a randomized complete block design with three replications. In this experiment, sprouted seeds were sown on well prepared puddle land. Direct seeding was done by using Drum Seeder. Unit plot size was $8 \mathrm{~m}^{2}$. Thinning was done at proper time. Fertilizer was applied @ 150: 100: 70: 60: $10 \mathrm{~kg}$ / ha Urea, TSP, MP, Gypsum and $\mathrm{ZnSO}_{4}$ respectively. Basal: 1/4 Urea, Full dose of TSP, Gypsum, $\mathrm{ZnSO}_{4}$, 2/3MP; Top dressing: 1/4 Urea (15-20 DAT), 1/4 Urea (35-40 DAT), $1 / 4$ Urea (booting stage) and $1 / 3 \mathrm{MP}$ at $2^{\text {nd }}$ top dress of urea. Water management; weeding and insects \& pest control was done when it is required. Data was collected from ten randomly selected plants from each plot on plant height $(\mathrm{cm})$, number of effective tillers/hill, number of panicles $/ \mathrm{m}^{2}$ flag leaf length, days to $50 \%$ flowering, spikelet fertility (\%), panicle length (cm), thousand grain weight (TGW) and plot yield (t/ha).

The analysis of variance was done using MSTAT C software. Genotypic and phenotypic coefficients of variation were estimated as per Singh and Chaudhary (1979). The broad sense heritability and genetic advance in percent of mean were calculated as suggested by Jonson et al. (1955). Normal Pearson's correlation was calculated using SPSS 10.0 software. Genotypic and phenotypic correlation coefficients were calculated following Miller et al. (1958). Path coefficient analysis was estimated according to the method suggested by Dewey and Lu (1959).

\section{RESULTS AND DISCUSSION}

The analysis of variance revealed highly significant variations among the varieties for all the characters studied (Table 1). The phenotypic variance was partitioned into genotypic and environmental variances for a clear understanding of the pattern of variations. The phenotypic coefficient of variation (PCV) was higher than genotypic coefficient of variation $(\mathrm{GCV})$ for all the characters studied indicating the presence of environmental influence to some degrees in the phenotypic expression of characters. GCV was the highest (21.58) for grain yield followed by flag leaf length (12.14) and days to $50 \%$ flowering (10.04) indicating higher degree of genetic variability among the tested hybrid for these traits. Similar results were obtained by Anseri et al. (2010) at different maintainer lines of hybrid rice.

Heritability estimates in broad sense $\left(h^{2} b\right)$ were relatively higher for almost all the traits studied except for number of effective tillers per hill and spikelet fertility. Iftekharuddaula et al. (2001) also reported similar results in hybrid rice. High heritability estimates have been found to be helpful in making selection of superior genotypes on the basis of phenotypic performance. Heritability estimates along with genetic gain would be more useful for selecting the best individual. High heritability associated with high genetic advance were found in panicle per $\mathrm{m}^{2}$ which indicated that the character was simply inherited in nature and controlled by few major genes or possessed additive gene effects.

These results were in agreement with Khaleda et al. (2004) in hybrid rice. The heritability estimates with low genetic advance indicated that non additive type of gene action and genotype $\mathrm{x}$ environment interaction played a significant role in the expression of the traits as observed in number of effective tillers/hill, grain yield, thousand grain weight, panicle length and days to maturity. 
Table 1. Genetic parameters of different yield and yield contributing characters of hybrid rice

\begin{tabular}{|c|c|c|c|c|c|c|c|c|c|c|}
\hline & $\begin{array}{c}\text { Plant } \\
\text { height } \\
(\mathrm{cm})\end{array}$ & $\begin{array}{c}\text { No. of } \\
\text { effective } \\
\text { tillers/hill }\end{array}$ & $\begin{array}{c}\text { Days to } 50 \% \\
\text { flowering }\end{array}$ & $\begin{array}{l}\text { Flag leaf } \\
\text { length } \\
(\mathrm{cm})\end{array}$ & $\begin{array}{c}\text { Panicle } \\
\text { length }(\mathrm{cm})\end{array}$ & $\begin{array}{c}\text { No. of } \\
\text { Panicles } \\
/ \mathrm{m}^{2}\end{array}$ & $\begin{array}{c}\text { Spikelet } \\
\text { fertility } \\
(\%)\end{array}$ & $\begin{array}{l}\text { Days to } \\
\text { maturity }\end{array}$ & $\begin{array}{l}\text { Thousand } \\
\text { grain weight } \\
\text { (g) }\end{array}$ & $\begin{array}{l}\text { Grain } \\
\text { Yield } \\
\text { (t/ha) }\end{array}$ \\
\hline MS & $128.72 * *$ & $0.99 * *$ & $177.90 * *$ & $40.67^{* *}$ & $13.78 * *$ & $938.41 * *$ & $68.36^{* *}$ & $256.63 * *$ & $11.61 * *$ & $1.16^{* *}$ \\
\hline$\sigma^{2} p$ & 44.17 & 0.78 & 58.45 & 14.08 & 5.17 & 348.17 & 84.23 & 5.17 & 3.61 & 0.43 \\
\hline$\sigma^{2} \mathrm{~g}$ & 39.61 & 0.05 & 57.01 & 12.63 & 4.30 & 303.76 & 22.78 & 86.68 & 3.47 & 0.37 \\
\hline$\sigma^{2} \mathrm{e}$ & 4.56 & 0.73 & 1.44 & 1.45 & 0.87 & 44.41 & 61.45 & 0.87 & 0.15 & 0.06 \\
\hline $\mathrm{H}^{2} \mathrm{~b}(\%)$ & 89.68 & 6.84 & 97.54 & 89.68 & 83.18 & 87.25 & 27.04 & 96.77 & 95.97 & 85.95 \\
\hline $\mathrm{GA}$ (\% of mean) & 12.28 & 0.12 & 15.36 & 6.93 & 3.90 & 33.54 & 5.11 & 3.90 & 3.76 & 1.16 \\
\hline GCV & 6.34 & 3.16 & 10.04 & 12.14 & 8.68 & 7.23 & 7.45 & 8.68 & 7.74 & 21.58 \\
\hline PCV & 6.69 & 12.08 & 10.17 & 12.82 & 9.51 & 7.74 & 14.33 & 9.51 & 7.90 & 23.28 \\
\hline $\mathrm{ECV}$ & 2.15 & 11.66 & 1.59 & 4.12 & 3.90 & 2.76 & 12.24 & 3.90 & 1.59 & 8.72 \\
\hline
\end{tabular}

MS = Mean sum of square, $\sigma^{2} g=$ Genotypic variance, $\sigma^{2} p=$ Phenotypic variance, GCV = Genotypic coefficient of variation, PCV $=$ Phenotypic coefficient of variation, $h^{2} b=$ Heritability (Broad sense) and GA $(\%)=$ Genetic advance in percent of mean

Table 2. Pearson correlation coefficient among yield and yield contributing characters in hybrid rice

\begin{tabular}{|c|c|c|c|c|c|c|c|c|c|}
\hline & $\begin{array}{c}\text { Number of effective } \\
\text { tillers/hill }\end{array}$ & $\begin{array}{l}\text { Days to } 50 \% \\
\text { flowering }\end{array}$ & $\begin{array}{c}\text { Flag leaf } \\
\text { length }(\mathrm{cm})\end{array}$ & $\begin{array}{c}\text { Panicle length } \\
(\mathrm{cm})\end{array}$ & $\begin{array}{l}\text { Number of } \\
\text { panicles } / \mathrm{m}^{2}\end{array}$ & $\begin{array}{c}\text { Spikelet } \\
\text { fertility (\%) }\end{array}$ & $\begin{array}{l}\text { Days to } \\
\text { maturity }\end{array}$ & $\begin{array}{l}\text { Thousand grain } \\
\text { weight }(\mathrm{g})\end{array}$ & $\begin{array}{l}\text { Grain yield } \\
\text { (t/ha) }\end{array}$ \\
\hline Plant height $(\mathrm{cm})$ & 0.09 & -0.04 & $0.52 * *$ & $0.36^{* *}$ & $0.27 *$ & 0.08 & -0.13 & $0.53 * *$ & 0.20 \\
\hline Number of effective tillers/hill & & $-0.27 *$ & 0.18 & -0.01 & $0.64 * *$ & $0.37 * *$ & $-0.29 *$ & $0.29 *$ & $0.34 * *$ \\
\hline Days to $50 \%$ flowering & & & 0.05 & -0.01 & $-0.38 * *$ & $-0.34 * *$ & $0.92 * *$ & -0.09 & $-0.42 * *$ \\
\hline Flag leaf length $(\mathrm{cm})$ & & & & 0.17 & $0.29 *$ & -0.01 & -0.12 & 0.18 & -0.02 \\
\hline Panicle length $(\mathrm{cm})$ & & & & & 0.12 & $0.28 *$ & -0.15 & $0.44 * *$ & 0.17 \\
\hline Number of panicles $/ \mathrm{m}^{2}$ & & & & & & $0.35 * *$ & $-0.41 * *$ & $0.34 * *$ & $0.51 * *$ \\
\hline Spikelet fertility (\%) & & & & & & & $-0.36 * *$ & $0.33 * *$ & $0.60 * *$ \\
\hline Days to maturity & & & & & & & & -0.18 & $-0.43^{* *}$ \\
\hline Thousand grain weight & & & & & & & & & $0.41 * *$ \\
\hline
\end{tabular}

** Significant at $1 \%$ level of probability, * Significant at $5 \%$ level of probability 
Table 3. Genotypic $(\mathrm{G})$ and phenotypic $(\mathrm{P})$ correlations among yield and yield contributing characters in hybrid rice

\begin{tabular}{|c|c|c|c|c|c|c|c|c|c|c|}
\hline Characters & & $\begin{array}{l}\text { Number of } \\
\text { effective } \\
\text { tillers/hill }\end{array}$ & $\begin{array}{c}\text { Days to } \\
50 \% \\
\text { flowering }\end{array}$ & $\begin{array}{c}\text { Flag leaf } \\
\text { length } \\
(\mathrm{cm})\end{array}$ & $\begin{array}{l}\text { Panicle } \\
\text { length } \\
(\mathrm{cm})\end{array}$ & $\begin{array}{c}\text { Number of } \\
\text { panicles } \\
/ \mathrm{m}^{2}\end{array}$ & $\begin{array}{c}\text { Spikelet } \\
\text { fertility }(\%)\end{array}$ & $\begin{array}{l}\text { Days to } \\
\text { maturity }\end{array}$ & $\begin{array}{l}\text { Thousand } \\
\text { grain } \\
\text { weight }(\mathrm{g})\end{array}$ & $\begin{array}{l}\text { Grain yield } \\
\text { (t/ha) }\end{array}$ \\
\hline \multirow{2}{*}{ Plant height $(\mathrm{cm})$} & G & 0.260 & -0.036 & $0.589 * *$ & $0.454 * *$ & $0.339 *$ & 0.090 & -0.151 & $0.579 * *$ & 0.204 \\
\hline & $\mathrm{P}$ & 0.105 & -0.032 & $0.516^{* *}$ & $0.363^{* *}$ & 0.003 & 0.075 & -0.545 & 0.532 & 0.206 \\
\hline \multirow{2}{*}{ Number of effective tillers/hill } & G & & $-0.506^{*}$ & 0.336 & 0.015 & $0.655 * *$ & $0.502 * *$ & $-0.514 *$ & $0.564 *$ & $0.706 * *$ \\
\hline & $\mathrm{P}$ & & $-0.270^{*}$ & 0.171 & -0.003 & $0.645 * *$ & $0.375^{* *}$ & $-0.450^{*}$ & $0.297 *$ & $0.351 * *$ \\
\hline \multirow{2}{*}{ Days to $50 \%$ flowering } & G & & & 0.037 & -0.015 & $-0.427 * *$ & $-0.408 * *$ & $0.980 * *$ & -0.098 & $-0.462 * *$ \\
\hline & $\mathrm{P}$ & & & 0.050 & -0.011 & $-0.385 * *$ & $-0.342 * *$ & $0.854 * *$ & -0.088 & $-0.429 * *$ \\
\hline \multirow{2}{*}{ Flag leaf length $(\mathrm{cm})$} & G & & & & 0.196 & $0.280 *$ & 0.048 & -0.123 & 0.195 & 0.017 \\
\hline & $\mathrm{P}$ & & & & 0.180 & $0.295^{*}$ & -0.007 & -0.509 & 0.188 & 0.003 \\
\hline \multirow{2}{*}{ Panicle length $(\mathrm{cm})$} & G & & & & & 0.143 & $0.372 *$ & -0.135 & $0.487 * *$ & 0.232 \\
\hline & $\mathrm{P}$ & & & & & 0.122 & $0.276^{*}$ & -0.635 & $0.437 * *$ & 0.173 \\
\hline \multirow{2}{*}{ Number of panicles $/ \mathrm{m}^{2}$} & G & & & & & & $0.431 * *$ & $-0.459 * *$ & $0.388 * *$ & $0.566 * *$ \\
\hline & $\mathrm{P}$ & & & & & & $0.347 * *$ & $-0.354 * *$ & $0.346 * *$ & $0.509 * *$ \\
\hline \multirow{2}{*}{ Spikelet fertility (\%) } & G & & & & & & & $-0.435 * *$ & $0.381 * *$ & $0.775 * *$ \\
\hline & $\mathrm{P}$ & & & & & & & $-0.354 * *$ & $0.325 * *$ & $0.614 * *$ \\
\hline \multirow{2}{*}{ Days to maturity } & G & & & & & & & & -0.193 & $-0.503 * *$ \\
\hline & $\mathrm{P}$ & & & & & & & & -0.761 & $-0.420 * *$ \\
\hline \multirow{2}{*}{ Thousand grain weight (g) } & G & & & & & & & & & $0.458 * *$ \\
\hline & $\mathrm{P}$ & & & & & & & & & $0.411 * *$ \\
\hline
\end{tabular}

** Significant at $1 \%$ level of probability, * Significant at $5 \%$ level of probability 
Pearson correlation analysis among yield and its contributing characters are shown in Table 2. For clear understanding correlation coefficients are separated into genotypic and phenotypic level (Table 3 ). The genotypic correlation coefficients in most cases were higher than their phenotypic correlation coefficients indicating the genetic reason of association. In some cases phenotypic correlation coefficient were higher than genotypic correlation indicating suppressing effect of the environment which modified the expression of the characters at phenotypic level. Grain yield was positively correlated with number of effective tillers per hill, panicle length, spikelet fertility and thousand grain weight. Eradasappa et al. (2007) reported significant positive correlation for spikelet fertility percentage with yield in rice. Days to 50\% flowering and days to maturity was negatively correlated with yield that means early maturing variety produced lower yield.

Plant height showed significant and positive correlation with flag leaf length and panicle length was significant both at genotypic and phenotypic level (Table 3). Mirza et al. (1992) reported positive correlation of number of panicles $/ \mathrm{m}^{2}$ and grain yield with number of tillers/plant. Thousand grain weights were positive and significantly correlated with plant height at genotypic level. Number of effective tillers per hill had negative significant association with days to $50 \%$ flowering and days to maturity but positive significant association with panicle $/ \mathrm{m}^{2}$, spikelet fertility, thousand grain weight and grain yield both at genotypic and phenotypic level.

Flag leaf length had positive significant association with panicle $/ \mathrm{m}^{2}$ both at genotypic and phenotypic level but no significant impact with yield. Panicle length had positive and significant association with spikelet fertility and thousand grain weight. Panicle $/ \mathrm{m}^{2}$ was positively and significantly correlated with spikelet fertility thousand grain weight and grain yield but negative significant association with days to maturity both at genotypic and phenotypic level. Kumar et al. (1998) observed high positive correlation of grain yield with spikelet fertility. Spikelet fertility exhibited negative significant association with days to maturity but positive significant association with thousand grain weight and grain yield both at genotypic and phenotypic level. Thousand grain weight exhibited positive significant association with yield both at genotypic and phenotypic level.

Path coefficient analysis (Table 4) revealed that spikelet fertility and panicle $/ \mathrm{m}^{2}$ possessed the highest positive effect on grain yield followed by thousand grain weight and number of effective tillers per hills. This indicates that more filled grain in panicle is the highly reliable component of grain yield. Another important character with high direct effect on seed yield is panicle $/ \mathrm{m}^{2}$ which showed positive direct effect on seed yield. Hence, spikelet fertility and panicle $/ \mathrm{m}^{2}$ should be given prior attention in rice improvement program because of their major influence on yield. This finding was in accordance with Hasan et al. (2010). Days to 50\% flowering and days to maturity had negative significant effect with yield. Negative direct effect was observed for number of effective tillers/plant, flag leaf length, panicle length and days to maturity. The residual effect of the present study was 0.677 , indicating that $32.5 \%$ of the variability in grain yield was contributed by ten characters studied in the path analysis. This result gives an impression that some other major characters than those involved in the present study might also contribute to yield. 
Table 4. Path analysis showing direct and indirect effects of yield components on hybrid rice

\begin{tabular}{|c|c|c|c|c|c|c|c|c|c|c|c|}
\hline \multirow[b]{2}{*}{ Traits } & \multirow[b]{2}{*}{$\begin{array}{l}\text { Direct } \\
\text { effects }\end{array}$} & \multicolumn{9}{|c|}{ Indirect effect } & \multirow[b]{2}{*}{$\begin{array}{l}\text { Pearson } \\
\text { correlation } \\
\text { with yield }\end{array}$} \\
\hline & & $\begin{array}{l}\text { Plant } \\
\text { height } \\
(\mathrm{cm})\end{array}$ & $\begin{array}{l}\text { Number of } \\
\text { effective } \\
\text { tillers/hill }\end{array}$ & $\begin{array}{c}\text { Days to } \\
50 \% \\
\text { flowering }\end{array}$ & $\begin{array}{l}\text { Flag leaf } \\
\text { length } \\
(\mathrm{cm})\end{array}$ & $\begin{array}{l}\text { Panicle } \\
\text { length } \\
(\mathrm{cm})\end{array}$ & $\begin{array}{c}\text { Number of } \\
\text { panicles } \\
/ \mathrm{m}^{2}\end{array}$ & $\begin{array}{c}\text { Spikelet } \\
\text { fertility } \\
(\%)\end{array}$ & $\begin{array}{l}\text { Days to } \\
\text { maturity }\end{array}$ & $\begin{array}{l}\text { Thousand } \\
\text { grain } \\
\text { weight }(\mathrm{g})\end{array}$ & \\
\hline Plant height $(\mathrm{cm})$ & 0.079 & - & -0.011 & -0.001 & -0.087 & -0.034 & 0.093 & 0.035 & 0.022 & 0.098 & 0.20 \\
\hline Number of effective tillers/hill & -0.121 & 0.007 & - & -0.003 & -0.030 & 0.002 & 0.222 & 0.156 & 0.041 & 0.053 & $0.34 * *$ \\
\hline Days to $50 \%$ flowering & 0.010 & -0.003 & 0.033 & - & -0.009 & 0.001 & -0.133 & -0.147 & -0.156 & -0.016 & $-0.42 * *$ \\
\hline Flag leaf length $(\mathrm{cm})$ & -0.168 & 0.041 & -0.021 & 0.001 & - & -0.016 & 0.099 & -0.005 & 0.020 & 0.033 & -0.02 \\
\hline Panicle length $(\mathrm{cm})$ & -0.094 & 0.029 & 0.002 & -0.001 & -0.029 & - & 0.041 & 0.119 & 0.025 & 0.081 & 0.17 \\
\hline Number of panicles $/ \mathrm{m}^{2}$ & 0.347 & 0.021 & -0.077 & -0.004 & -0.048 & -0.011 & - & 0.148 & 0.070 & 0.064 & $0.51 * *$ \\
\hline Spikelet fertility (\%) & 0.428 & 0.007 & -0.044 & -0.003 & 0.002 & -0.026 & 0.120 & - & 0.062 & 0.060 & $0.60 * *$ \\
\hline Days to maturity & -0.170 & -0.010 & 0.035 & 0.009 & 0.020 & 0.014 & -0.143 & -0.155 & - & -0.034 & $-0.43 * *$ \\
\hline Thousand grain weight (g) & 0.185 & 0.042 & -0.035 & -0.001 & -0.030 & -0.041 & 0.119 & 0.139 & 0.031 & - & $0.41 * *$ \\
\hline
\end{tabular}

\section{Residual effect: 0.677}

** Significant at $1 \%$ level of probability, * Significant at $5 \%$ level of probability 


\section{REFERENCES}

Ansari, A., A. W. Julfiquar, M. G. Rasul, M. J. Hasan and M. M. Rahman. 2010. Genetic parameter, correlation and path analysis for yield and yield related traits in some maintainer lines of hybrid rice (Oryza sativa L). Eco-friendly Agril. J. 3(2): 8995.

Ashikari, M., H. Sakakibara, S. Lin, T. Yamamoto and T. Takashi. 2005. Cytokinin oxidase regulates rice grain production. Science. 309: 741-745.

Dewey, D. R. and K. I. Lu. 1959. A correlation and path coefficient analysis of components of created wheat grass seed production. Agronomy Journal. 515518.

Eradasappa E, N. Nadarajan, K. N. Ganapathy, J. Shanthala and R. G. Satish. 2007. Correlation and path analysis for yield and its attributing traits in rice (Oryza sativa L.). Crop Research 34 (1\&2): 156-159.

Hasan, M. J., M. U. Kulsum, N. Hoque, M. A. Miah and F. A. M. S. Azam 2010. Genetic variability, correlation and path coefficient analysis in some restorer lines of hybrid rice (Oryza sativa L.). Eco-friendly Agril. J. 3(5): 222-226.

Honarnejad, R., S. Abdollahi, M. S. Mohammad-Salehi and H. Dorosti. 2000. Consideration of adaptability and stability of grain yield of progressive rice (Oryza sativa L.) lines. Res. Agric. Sci. 1: 1-9.

Iftekharuddaula, K. M., M. S. Hasan, M. J. Islam, M. A. Badshah, M. R. Islam and Khaleda Akter. 2001. Genetic evaluation and selection criteria of hybrid rice in irrigated ecosystem of Bangladesh. Pakistan Journal of Biological Sciences, 4(7): 790-792.

Jonson, H. W., H. F. Robinson and R. E. Comstock. 1955. Estimates of genetic and environmental variability in soybean. Agronomy Journal. 47(7): 314-318.

Khaleda, A., K. M. Iftekharuddaula, M. K. Bashar, M. H. Kabir and M. Z. A. Sarkar. 2004. Genetic variability, correlation and path analysis in irrigated hybrid rice. J. Subtrop. Agric. Res. Dev. 2(1): 17-23.

Kumar, G. S., M. Mahadevappa and M. Rudraradhya. 1998. Studies on genetic variability, correlation and path analysis in rice during winter across the locations. Karnataka Journal of Agricultural Science, 11(1): 73-77.

Miller, P. A., C. Williams, H. F. Roginson and R. E. Comstock. 1958. Estimates of genotypic and environmental variance and covariance and implication in section. Agronomy Journal. 50: 126-131.

Mirza, M.J., F.A. Faiz and A. Mazid. 1992. Correlation studies and path analysis of plant height, yield and yield components in rice (Oryza sativa L). Sarhad J. Agric., 8(6): 647-653.

Singh R. K. and B. D. Chaudhary. 1979. Biometrical methods in quantitative genetic analysis. Kalyani publication, New Delhi, 120 p.

Srividya, A., L. R. Vemireddy, A. S. Hariprasad, M. Jayaprada and S. Sridhar. 2010. Identification and mapping of landrace derived QTL associated with yield and its components in rice under different nitrogen levels and environments. Int. J. Plant Breed. Genet. 4: 210-227. 